реальным желаниям трудового народа. Противоречие властных установок народным чаяниям создаёт неустойчивое общественное состояние. Может быть, поэтому состоятельные люди, олигархи держат свои сбережения в заграничных банках. Но это уже другой вопрос, вопросо социальной устойчивости буржуазного общества России.

1. Баглай М.В. Конституционное право РФ. Учебник для юридических вузов. Москва, 2000, с. 18.

2. Ленин В.И. Как социалисты - революционеры подводят итоги революции //ПСС, т. 17, с. 345.

3. Минкин А. Подрывники, 55 кинжалов в спину российского суда. //«Московский комсомолец. РРЕ», 5-16 марта 2011, №11, с. 4.

4. Чумаков В. А. К вопросу становления философии регулятивно-диалектического материализма //Научный диалог: вопросы философии, социологии, истории, политологии. Сборник научных трудов по материалам международной научной конференции 1 октября 2016г. LJournal.ru. Самара 2016, часть 1. Издание ЦНК МНИФ «Общественные науки», с. 5-11.

\title{
Prawirayuda G.A.
}

\section{Concept of International Commercial Arbitration Practice in the Russian Federation}

\author{
Peter the Great St.Petersburg Polytechnic University
} (Russia, St.Petersburg)

doi:10.18411/spc-20-01-2018-10

idsp: 000001:spc-20-01-2018-10

Arbitration is the most formal alternative to litigation. In this process, the disputing parties present their case to a neutral third party, who renders a decision. Arbitration is widely used to resolve disputes in both the private and public sector.Governing Laws The Russian Constitution regards international treaties to which Russia is a party as an essential and supreme component of Russian law. Thus, international treaty and convention rules prevail in the event of a conflict with domestic Russian law. With respect to international arbitration, Russia is a party to the Convention on the Recognition and Enforcement of Foreign Arbitral Awards of 1958 (New York Convention) and the European Convention on International Commercial Arbitration of 1961. Russia is also a party to several bilateral treaties on the mutual recognition and enforcement of arbitral awards, including, for example, with Sweden and Japan.

Regional treaties with other Commonwealth of Independent States ("CIS") countries are an important source of law in intra-CIS disputes.The primary source of Russian international arbitration law is the law "On International Commercial Arbitration" (International Arbitration Law) enacted on July 7, 1993.The International Arbitration Law is based on the UNCITRAL Model Law; however, Russia has not adopted the amendments to the UNCITRAL Model Law that were introduced in 2006. In addition to the International Arbitration Law, ancillary rules governing interface between the courts and arbitral tribunals are set out in the Arbitrazh Procedure Code (APC).The arbitrazh courts are federal commercial courts which, in 2002, assumed responsibility from the courts of general jurisdiction for the enforcement of foreign arbitral awards and judicial support of arbitration proceedings generally.

Arbitration has several concepts that are also an arbitrage advantage compared to ordinary courts. These advantages are directly related to the principles of international commercial arbitration, the main of which are as follows:

\section{The Principle of Rapidity.}

As a rule, the time for consideration of cases in the state arbitration court is longer (the total time for consideration of cases in the courts of the first, appeal, cassation and supervisory instances is at least one year) compared with the proceedings in international commercial arbitration. The Rules of the International Commercial Arbitration Court at the Chamber of Commerce and Industry of the Russian Federation contain an indication of the 
maximum period allowed for an arbitral award. It is 180 days, which is in common with the most authoritative Western arbitration institutions, most of which also establish a six-month period during which the dispute must be resolved. In our opinion, this is a sufficient period during which the arbitrators can objectively and comprehensively investigate the circumstances of the case, and the parties state all the arguments and arguments. Foreign economic transactions are often concluded for a long period of time, and proper execution of the contract requires regular actions of both parties, therefore, in the event of a conflict, there is objectively a need for an early settlement of the dispute for the continuation of partnership relations.

\section{The Principle of Neutrality And Internationalism.}

Compared with the appeal to state courts in the ICA, it is possible for the parties to influence the composition of the panel of arbitrators, providing a truly independent, objective and competent consideration of the dispute, which is called "control over the process". As noted in 2010 in the directory of international arbitration, $66 \%$ of the surveyed experts of the world's leading companies consider it to be the main advantage of international arbitration that its neutrality and internationalism are qualities not typical of most state courts.

\section{The Principle of Economic Justice.}

In commercial arbitration, the arbitrator does not investigate and does not claim all possible evidence in the case as in state courts, but analyzes only the evidence presented by the parties within the time limits provided by the ICA rules, the arbitration schedule, and the arbitration agreement. If the time limit for presenting evidence is violated without justifiable reasons, the arbitration does not accept them for consideration, which significantly shortens the time frame for the decision, which the parties can recognize as final.

\section{The Principle of Parity of Interests And Business Relations.}

Each partnership is unique, therefore, imperative norms and strictly formalized procedures offered by state legal proceedings are often not appropriate for their preservation. The arbitration agreement, developing in line with the strengthening of the principles of flexibility and autonomy of the will of the parties, allows the parties to jointly develop precisely those measures and forms of behavior in case of conflict that are acceptable in order to maintain the stability of this particular contract and the loyalty of the relations of these specific participants in foreign economic activity.

\section{Freedom of Expression of Will When Choosing The Law to Be Applied.}

The parties of their choice may elect by arbitration agreement as applicable the right of one of the parties or the right of any other country. It is also possible to use lex mercatoria as transnational commercial law as an applicable law. It should be noted that recently dynamically developing international commercial practice increasingly indicates the continuing desire of the business community to use norms and principles of an informal nature that are of international origin in settling disputes in the ICA, which was chosen by the parties instead of appealing to the jurisdiction of national courts, as contractors are guided on the autonomy inherent in international arbitration, the flexibility and fairness of arbitration. Moreover, studies have shown that the business community prefers applying transnational informal norms to the traditional dogmatic approach, primarily for pragmatic reasons, since in this case this method of solving international commercial disputes more closely matches their expectations.

In accordance with Art. 33 of the UNCITRAL Arbitration Rules it is permissible to make a decision on the basis of ex aequo et bono, if the parties directly authorized the ICA to do so, and if the law governing the arbitration process admits such arbitration. Ex aequo et bono is translated as "in justice and good conscience"; Under this procedure, the court is not bound by specific norms of national law, but can be guided by considerations of justice and common sense. This order since January 1, 1998 is established in the German legislation. In paragraph 1051 of the German Civil Procedural Code, it is provided that the arbitral tribunal shall resolve the case in fairness, if the parties have authorized it to do so. This approach is 
not unique, so, according to Art. 14.3 of the Scotland Arbitration Act, the parties may reach an agreement on the resolution of a dispute by the arbitral tribunal ex bono et aequo.

\section{The Principle of Confidentiality.}

As a rule, hearings in state courts are held in public meetings, and their decisions can be published in full, whereas in the ICA cases are dealt with in closed sessions, and decisions, if they are published, without indicating the disputing parties and with their consent. This circumstance is an indisputable advantage of the ICA before the state courts, especially for foreign investors, when information on the presence of a conflict can lead to a diminishing of business reputation and adversely affect the future activities.

\section{The Principle of Professionalism and Disinterestedness of The Arbitrator.}

Arbitration groups are formed by consent of the parties from highly qualified specialists who have the necessary knowledge to resolve the dispute, are competent in the sphere of conflict and have a recognized and irreproachable reputation.

\section{Conclusion}

Arbitration is the most formal alternative to litigation. In this process, the disputing parties present their case to a neutral third party, who renders a decision. Arbitration is widely used to resolve disputes in both the private and public sector.

Arbitration is generally considered a more efficient process than litigation because it is quicker, less expensive, and provides greater flexibility of process and procedure. The parties often select the arbitrator and exercise control over certain aspects of the arbitration procedure. Arbitrators typically have more expertise in the specific subject matter of the dispute than do judges. They may also have greater flexibility in decision-making.In addition, the arbitration is selected and in the application within the Russian Federation because of the concept of the arbitration itself is good.

Among others are:

1. The principle of rapidity.

2. The principle of neutrality and internationalism.

3. The principle of economic justice.

4. The principle of parity of interests and business relations.

5. Freedom of expression of will when choosing the law to be applied.

6. The principle of confidentiality.

7. The principle of professionalism and disinterestedness of the arbitrator.

$$
* * *
$$

1. Berger K. The CENTRAL Enquiry on the Use of Transnational Law in International Contrac Law and Arbitration - Selected Results from the First Worldwide Survey on the Practice of Transnational Commercial Law // ASA Bulletin. 2000. P. 667.

2. Federal Law No. 95-FZ, "Arbitrazh Procedure Code of the Russian Federation.

3. Kyiv Agreement On Procedure of Settling Disputes with. Regard to Carrying on Business Activities of March 20, 1992; Minsk Convention on Legal Assistance and Legal Relations in Civil, Family and Criminal Matters of January 221993 (see http://www.unhcr.org/4de4edc69.html); Kishinev Convention on Legal Assistance and Conflicts of Law in Matters of Civil, Family and Criminal Law of October 7, 2002.

4. The Constitution of the Russian Federation, published in Rossiiskaya Gazeta, Dec. 25, 1993, part 4, art. 15.

5. Гражданское процессуальное уложение Германии. Под ред. В. Бергман. М., 2006. С. 363

6. Закон РФ “О международном коммерческом арбитраже" [Law on International Commercial Arbitration], Vedomosti RF, 1993, No. 32, Item 1240. For an English translation of the International Arbitration Law, see http://www.jus.uio.no/lm/russia. international.commercial.arbitration.1993/doc.html.

7. Иншакова А. О., Антипов И. Позитивные факторы и гибкие правовые средства развития международного коммерческого арбитража // Вестник Волгоградского государственного университета. Серия 5. Юриспруденция. 2014. № 1 (21). С. 30-39. 